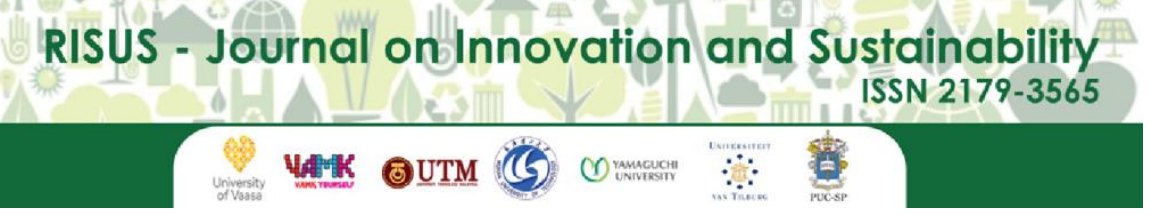

RISUS - Journal on Innovation and Sustainability volume 11, número 3 - 2020

ISSN: $2179-3565$

Editor Científico: Arnoldo José de Hoyos Guevara Editor Assistente: Rosa Rizzi

Avaliação: Melhores práticas editoriais da ANPAD

\title{
MAPPING THE DIMENSIONS OF HUMAN RESOURCES DEVELOPMENT: A SCOPING REVIEW
}

Mapeando as dimensões do desenvolvimento de recursos humanos: uma revisão do scoping

Kazi Nazmul Huda

Southern University Bangladesh

E-mail:knhuda@yahoo.com

\begin{abstract}
Human Resource Development (HRD) is a precondition of economic growth, political stability and social sustainability. HRD intervention may facilitate achieving high-performance standards at individual, organizational, national, and international echelon. The paper is designed to explore and catalog different dimensions and variables of HRD through a critical review of existing literature. Hence, the opinion of HRD experts was collected through focus group discussion and face to face interview to authenticate the explored variables of HRD. The study has explored different dimensions and variables of HRD with regard to inputs, objectives, interventions, outputs, outcomes, and beneficiaries of HRD comprehensively by using the scoping review technique. The study has contributed to the existing body of knowledge by providing a new definition of HRD and presenting its different dimensions systematically. There is an immense scope to develop further knowledge on HRD if the empirical validity of the HRD variables is investigated comprehensively.

Keywords: Human Resource Management, Human Resource Development, National Human Resource Development, and Regional Human Resource Development.
\end{abstract}




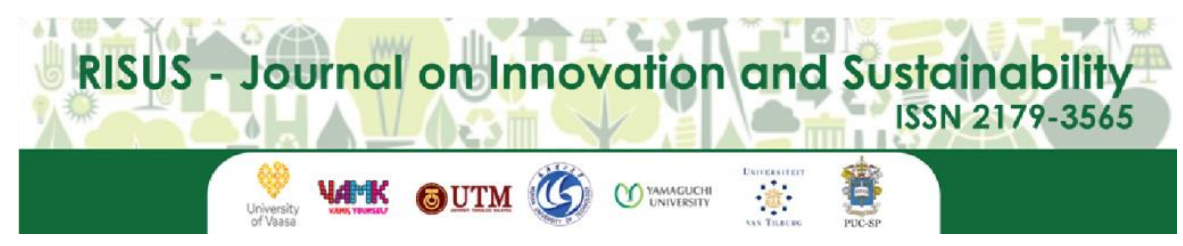

RISUS - Journal on Innovation and Sustainability volume 11, número 3 - 2020

ISSN: $2179-3565$

Editor Científico: Arnoldo José de Hoyos Guevara Editor Assistente: Rosa Rizzi Avaliação: Melhores práticas editoriais da ANPAD

\title{
MAPEANDO AS DIMENSÕES DO DESENVOLVIMENTO DE RECURSOS HUMANOS: UMA REVISÃO DO SCOPING
}

Mapping the dimensions of human resources development: a scoping review

\author{
Kazi Nazmul Huda \\ Southern University Bangladesh \\ E-mail:knhuda@yahoo.com
}

\section{RESUMO}

O Desenvolvimento de Recursos Humanos (DRH) é uma condição prévia para o crescimento econômico, estabilidade política e sustentabilidade social. A intervenção de DRH pode facilitar a obtenção de padrões de alto desempenho nos escalões individual, organizacional, nacional e internacional. $\mathrm{O}$ artigo foi elaborado para explorar e catalogar diferentes dimensões e variáveis de DRH por meio de uma revisão crítica da literatura existente. Portanto, a opinião de especialistas em DRH foi coletada por meio de discussão em grupo focal e entrevista face a face para autenticar as variáveis exploradas de DRH. O estudo explorou diferentes dimensões e variáveis de DRH com relação a entradas, objetivos, intervenções, produtos, resultados e beneficiários de DRH de forma abrangente, usando a técnica de revisão de escopo. O estudo contribuiu para o corpo de conhecimento existente, fornecendo uma nova definição de DRH e apresentando suas diferentes dimensões de forma sistemática. Há um imenso escopo para desenvolver mais conhecimento sobre DRH se a validade empírica das variáveis de DRH for investigada de forma abrangente.

Palavras-chave: Gestão de Recursos Humanos, Desenvolvimento de Recursos Humanos, Desenvolvimento Nacional de Recursos Humanos e Desenvolvimento Regional de Recursos Humanos. 


\section{INTRODUCTION}

Human resource is the prime element behind all organizations, nations, and society's growth and prosperity. It is the only renewable and sustainable resource available to a nation and indisputably the first and the major precondition for individual success and collaborative development (Saeed \& Batool, 2004). The concept of Human Resource Development (HRD) has been the most vital issue to shape development strategies worldwide (Bikas \& Sanyal, 1992). It has become an ideology of transforming humans into productive production input. It is also the most potent propeller of a country's economic growth and social development (Ather \& Solaiman, 1995). HRD endeavors to develop human potentials through several interventions to meet organizational objectives like productivity \& profitability and, at the same time, facilitates achieving national strategic needs like the welfare of people and socio-economic mobility.

It converts raw human beings into an effective element of production and at the fundamental level, creating value for socio-economic benefits. The concept of HRD is to create a framework that facilitates human resources to discover the potentials to achieve their best in life (Rao, 2000). It is a holistic approach and a hybrid process of creating an environment to search, stimulate, and shape the human potentials to facilitate productivity and growth commonly in all socioeconomic development interventions. Human resource development ensures the people's long and healthy lives at the minimum level, making them knowledgeable in a real sense, giving entrance to the wealth, standard lifestyle, and social life (Pande et al., 2006). HRD is an endeavor to shift human productivity from obsolesces to effectiveness and its interventions transform hard work into smart work.

Commonly, HRD is a hybrid process of systematizing, categorizing, and developing a physical and intellectual ability if an individual (Huda, Karim \& Ahmed, 2007). HRD fastens the human development interventions related to human competency enhancement through education, training programs, empowering people at the grassroots, promoting consciousness, formalizing teamwork, social capital development, change management, and other human capital management functions (Khan, Khan \& Mahmood, 2012). Traditional HRD concerns developing people intending to intensify the financial strength and, consequently, a nation's prosperity likened with socio-economic sustainability. Usually, the concept of Human development and Human resource development is somewhat linked with each other, and fundamentally, all HRD interventions are used to develop human productivity by developing their competency (knowledge, skill, and human behavior).

HRD is undoubtedly a fascinating subject, but at the same time, it is a confusing subject because the dimension of HRD is vast and integrative (Arya \& Tandon, 1998). It is surely an enthralling field of research, as several scopes of HRD have to be considered. As a subject, HRD is interdisciplinary and blends many topics of social sciences, public administration, and general management (Jayagopal, 1990). HRD concepts are discussed from many angles by different authors, and the contents are scattered. According to McGoldrick, Stewart and Watson (2001), HRD concepts are still confusing as there are limitations of sufficient empirical research. The knowledge of HRD is fragmented and not built in a comprehensive shape. This study endeavors a systematic indepth analysis to categorize the dimensions and variables of HRD and presented them systematically to facilitate further research work and also enriching the existing body of knowledge.

\section{OBJECTIVE}

The main objective of this study is to diagnose the concepts of HRD to discover and categorize its different dimensions and variables in a systematic way.

\section{LITERATURE REVIEW}

HRD is a process to unlock the door to modernization (Abdullah, 2009). It is the core thought of economic development that intervenes in different ways and dimensions to convert humans as resources (Sen, 2007). HRD is the key to economic progress in the era of digitalization, and there is a strong linkage between HRD and economic development (Briggs, 1987). The current wave of development in the new millennium, like the challenges of economic liberalization and globalization, has bought several opportunities for the nations and organizations to dominate in the world economy (Huda, 2020). HRD interventions may help to seize those 
opportunities and assist in surviving the threats. Though HRD is an essential economic development program through human capability development, most of the time, the initiative is wasted by the curse of unemployment, obsolesce of skills, lack of work opportunities, and hurdles of adjusting change (Green Berg \& Baron, 1997).

According to some recent literature by McLean \& McLean (2001); Harrison \& Kessels (2004); Hamlin 2004, and many others, HRD is considered as a process. On the other hand, Nadler (1970); Hamlin (2004); Werner \& DeSimone (2006), and many scholars coined it is a systematic activity or program. Nadler and Wiggs (1986); Harrison \& Kessels (2004); Watkins (2000) and others thought it is a comprehensive learning system. Hence, most of the HRD philosophers like Garavan (1991); Harbison \& Myers (1964); McLean \& McLean (2001) have universally agreed that knowledge, skill, and behavioral development are the critical inputs of HRD. Some researchers like Kuchinke (2003); Werner \& DeSimone (2006), added competency as a factor of HRD, and Watkins (2000) had discussed workability as an essential variable and emphasized on learning.

HRD initiatives facilitate the human capital development of a nation and help achieve success from an individual level to global. In the beginning, HRD was practiced mostly in corporate organizations. However, the growing interest of this discipline has explored beyond global development issues and has acknowledged the significance of acquiring advanced knowledge, skills, and competencies to achieve collective success (Kuchinke, 2003). Hence, a skilled workforce acts as the prime mover of knowledge-based economic growth at the macro and microeconomic level of HRD (Mezei \& Fodor, 2012). According to Tariq Khan (2013), HRD interventions are not limited to education, training, and capacity building programs but also have many other dimensions. It also includes health care, psychological/mental satisfaction (self-respect, incentives, job protection, better working condition, good salary, etc.). Therefore, the discipline of HRD has extended far from the traditional context of training \& development activities by an organization and includes the notion of strategic management, individual development, team learning, career assistance, and promoting the intellectual capital (Cunliffe \& Easterby-Smith, 2004; Walton, 1996). HRD covers planned activities and processes intending to improve organizational learning practices to increase human performance, maximize system effectiveness and leading sustainable change management (Hamlin, 2004).

According to Rawat (2008), HRD programs provide continuous support to the employees to obtain the necessary expertise, facilitate developing a performance-oriented organizational culture, and foster an employee's creative \& innovation skills. Interventions of HRD aid a workforce with state-of-art capabilities in achieving an enterprise's strategic objectives (Rawat, 2008). According to McLean et al. (2012), the foundation of HRD was primarily laid on organizational set-up. First, it was materialized in the American corporate culture to respond to global challenges. Later, the concept of HRD embarked on the common interest of human development as a whole at the community, national, and international stage. Kim (2012); Metcalfe, (2011); Tome' E. (2011) also sated the same in their articles.

Devadas, Silong \& Krauss (2011) have stated the potentiality of Modern Human Resource Development Practice to deal with the challenges of the new millennium. However, it is widely accepted by the renowned corporate as they have identified its significance in the holistic development of an organization (Rawat, 2008). The practice of HRD at the organizational level is considered as micro HRD (Tregaskis, Heraty \& Morley, 2001). It includes the following functions like employee development and interventions through training, skill upgradations, employee adaptation programs, performance management, behavioral interventions, organizational development interventions, change management activities, implementing quality of working life and work-life balancing, etc. For encountering the new millennium challenges, HRD actions will mostly involve the areas of human capacity development of the future workforce to attain new job assignments (Ford, 1993).

McLean \& Jiantreerangkoo (2020) had coined that the functions of HRD are applicable both at micro and macroeconomic stratum. However, it is concerned with the human development of grass-root-level employees at the micro-level, and macro HRD initiatives work for the common people in a country (Rao, 2000). The implication of HRD is staged at multiple levels like the individual, organizational, sectoral, national, transnational, and global (Wang \& Swanson 2008). According to Rawat (2008), HRD is commonly linked with the growth of a nation, but macro HRD is not a widely accepted practice like micro HRD, as practiced at the organizational level. According to Abdullah (2009), there are three classes of HRD, economic, political, and cultural. The economic term of HRD is to invest in human capital development, and the political term is to promote democracy. 
Moreover, the cultural dimension of HRD is to ensure richer lives to the people at large (Bates, Chih Chen \& Hatcher, 2002). National Human Resource Development (NHRD) works on strategy development areas, including national skill development, occupational training, management development initiatives, formal \& vocational education systems, and evaluation of such programs at the national level (Alagaraja, 2012).National level HRD activities ensure human development indicators like increasing life expectancy, making a country free from all the dimensions of poverty, developing social capital, and social harmony (Collins, Zarestky \& Tkachenko, 2017). According to Alagaraja \& Githens (2016), NHRD interventions are mostly associated with ensuring a people's welfare of a country where the government involves developing people's health status, and professional competencies of the working communities are helping to ensure the collective national growth. However, at the time of measuring the growth of gross national income and gross national product, NHRD also considers the dimensions like individual talent, social behavior attitudes, competency, personal ambition, and intellectuality (Rawat, 2008).

The HRD interventions applied to a broader perspective, mainly to the government or state level, are called Macro HRD (Senapaty, 2010). However, Wang \& Swanson (2008) mentioned that macro-level HRD or NHRD theories are not developed based on economic and systems theory. Byrd \& Demps (2006) also studied the concepts of NHRD by interviewing a couple of NHRD scholars and practitioners. The study suggested developing a partnership between HRD professionals and government machinery to develop human expertise and knowledge that brings the collective social and economic growth for the organizations, communities, nations, and societies. Hence, NHRD is also a process of developing knowledge, skills, and capacities of the people in a society (Harbison and Myers, 1964).

NHRD has been gestated as a notion of HRD to work on national policy issues (Cho and McLean, 2004). Macro-level HRD concerns labor policy formulation and development of the state of Industrial relations (Lashley \& Watson, (1999). Macro HRD or NHRD is responsible for developing citizens with the necessary skills and competence for productive work. According to McLean (2004), HRD at the national level is not only an endeavor to reduce the unemployment rate and labor management. Hence, it is a necessary intervention to ensure human welfare like health, cultural development, workers' safety, community development, and other human development activities beyond traditional human resource planning or investment in human capital development. McLean (2006) had stated about the inconceivable disparity of the world, like distribution of wealth, access to education, equal employment opportunities, access to primary health care, use of modern technology, advanced infrastructures, individual safety, and other factors that contribute to the human well-being. Therefore, a pathway should be mapped to minimize these inequalities by creating an effective collaboration among the citizens, practitioners, and researchers under the broader framework of NHRD.

Ali (2005) and Ali (2008) had focused on the HRD challenges of Asian countries. They have prioritized creative skill development programs by developing primary and secondary education curricula, upgrading the educational workforce, improving on-the-job training facilities, expanding scientific and technological development, and upgrading skills in the service sector. Liu \& Wall (2005) discusses the same NHRD interventions, i.e., education and training, in developing the tourism sector of China. Sarbabidya \& Huda (2004) had identified an apparent interrelation between NHRD and social development issues. They have tried to justify the contribution of NHRD in ensuring the real development of society, and the indicators of social development are poverty freeness, financial empowerment, good health, status equity, discrimination freeness, economic development, good management, etc. Hence, Saeed \& Batool (2004) emphasized on intellectual property development as a critical input of NHRD to encounter global economic challenges in this knowledge era.

NHRD is an essential strategy for economic and social progress that maximizes human potentials by enhancing an individual's physical, social, and mental capabilities and promoting socioeconomic progress (Kashem \& Guha, 2000). Ather \& Solaiman (1995) identified the stakeholders of NHRD starting from family, primary \& secondary schools, institutions, colleges \& universities, NGOs, private, vocational, and technical training centers, banking, commercial and industrial organizations, and finally, the government at the top. Alagaraja (2012) had tried to examine the concepts of NHRD, and the results of his study predict that the demand for unskilled workforce would decline gradually. However, a skilled national labor force will determine the competitive position in the global marketplace in the near future. 
MacLean (2004), coined that the function HRD goes beyond the corporate limits and incorporates the society, nations, regions, and the citizens of the global community, accommodating the variances in cultural values, political ideologies, and economic systems. The study of Ahn \& Mclean (2006) suggested extending the NHRD program by developing a regional integration of innovation systems among the countries in a specific geographical area through the Regional Human Resource Development (RHRD) program to strengthen regional development. According to Baek (2002), RHRD interventions consist of all the endeavors of the regional agencies to gain efficiency in all types of territorial development activities. It mainly ensures effective management and utilization of the regional workforce to maximize the quality of life, regional cooperation, and competitiveness.

Metcalfe \& Rees (2005) tried to theorize the emerging concepts of International HRD (IHRD). They tried to study the challenges of globalization and emphasized the importance of understanding the global HRD system by realizing the necessity of learning global cultural, demographic, and geographic differences to extend the knowledge of HRD beyond national limits. Hamlin \& Stewart (2011) have mentioned that IHRD should be an integrated and collective effort. It should be practiced by commercial enterprises, nonprofit development organizations, and state agencies for the systematic development of cross-national human recourses to developing an alliance for regional development. Many international development organizations recommend that regional human resource development (RHRD) strengthen the collective human development program in a specific geographical region (Kang, 2002).

The summary of the literature review exhibits HRD as a systematic process or an organized intervention for creating an opportunity to improve knowledge, skill, and attitude of human recourses through the systematic intervention of formal and informal training \& development program, education, health, technology, and infrastructure development to achieve individual, organizational, societal, national, regional, or international goals and strategies. However, it is quite evident from the literature review that HRD is a vast discipline that needs to be studied systematically, categorizing its contents in an orderly manner, which is somewhat missing in the current research work. This study will bridge the gap by exploring dimensions and critical variables of HRD to facilitate further research by enriching the existing body of knowledge.

\section{METHODOLOGY}

The author has adopted a subjective ontology and assumed a narrative epistemology and methodology to attain the research objectives. This is a qualitative study, and the necessary information and secondary data have been decisively compiled from previously published relevant research journals and reference books. The scoping review technique is applied to project a broader insight of HRD for mapping its key concepts, theories, and practices. This technique of literature review is suggested by many research scholars' like Colquhoun et al. (2014); Peters (2015); Gunnarsson (2020), which allows a researcher to unite different concepts of a particular field of study and helps to summarize the results of the study using tables, charts or info-graphic presentations. Complying with the technique mentioned above, the researcher had accumulated different variables of HRD irrespective of the country and field of study.

HRD is a relatively new discipline (Swanson, Holton \& Holton, 2001), and the modern concepts of this field of study mostly emerged during the last few decennia of the 20th century (Sarfin, 2017). Therefore, articles, books, and research monographs, mostly published from 1964 to 2020, were considered for review. One hundred research articles were selected for the literature review, and around 70 percent of the literature was qualitative. Most of the studies were conducted in developed countries, i.e., the USA and the UK. However, the author also considered the research conducted in developing nations like China, India, and Bangladesh.

At the second stage of the study, the sorted variables of HRD were verified through a judgmental opinion collected through a homogenous focus group discussion session with the Human Resource Management faculty members of different universities located in Bangladesh. This session was held in the departmental seminar room and lasted for three hours. A common criterion was used where any variable was considered relevant, whichever has got four out of five votes in the group. Besides, qualitative data were obtained through face-to-face in-depth interviews with the industry experts to validate the earlier findings. In-depth interview sessions were organized 
with three HRD scholars and three managers of Multi-National Corporations who have long experience working with the human resources department. Each session lasted for two hours, and the comments of the experts' were recorded in audiotapes. The results of the study are presented in tables and visually communicable figures using Microsoft Word SmartArt tools.

\section{DISCUSSIONS}

From the study, the dimensions and variables of HRD have been revealed. Initially, the dimension of HRD objective is identified, followed by the operational level and the key stakeholders or beneficiaries of HRD, the HRD inputs, process/interventions, outputs, and outcomes of HRD. However, the critical variables of the dimensions are listed in the table with sources.

\subsection{Definition of HRD}

The study defined HRD as an intelligent practice and a hybrid process of transforming human as a resourceful utility, targeting the individual, organizational, and the global development at large, through necessary social, technological, structural, and policy interventions at different operational hierarchy to achieve productivity, profitability, and sustainability.

\subsection{Objectives of HRD}

Table 1: Objectives of HRD

\begin{tabular}{|c|c|c|}
\hline Sl.No & Objectives & Source \\
\hline 1 & $\begin{array}{l}\text { Individual performance } \\
\text { Development }\end{array}$ & $\begin{array}{l}\text { Chalofsky \& Lincoln (1983); Smith (1988); Nadler \& Nadler (1989); } \\
\text { Garavan (1991); McLean \& McLean (2001); Harrison \& Kessels } \\
\text { (2004); McLagan \& Suhadolni (1989); Stewart (1999); Hamlin } \\
\text { (2004) }\end{array}$ \\
\hline 2 & Professional Development & Yorks, (2005); Gilley and Egglund (1989) \\
\hline 3 & Organizational Effectiveness & Rao (2000); McLagan \& Suhadolnik, (1989); Ahn\& McLean, (2006) \\
\hline 4 & Productivity & $\begin{array}{l}\text { McLean \& McLean (2001);Broad \& Newstrom (1992); Smith } \\
\text { (1988) }\end{array}$ \\
\hline 5 & Profitability & Smith (1988) \\
\hline 6 & Economic Growth & Briggs (1987) \\
\hline 7 & Leadership Development & Swanson (1987) \\
\hline 8 & Social Development & Sarbabidya \& Huda (2004) \\
\hline 9 & Political Stability & MacLean (2004) \\
\hline 10 & Cultural Enrichment & Abdullah (2009) \\
\hline 11 & Competitiveness & Huda, et al. (2014) \\
\hline 12 & Effective Change & Hamlin (2004) \\
\hline 13 & Social justice & Fenwick (2005) \\
\hline 14 & Employment Generation & Briggs (1987); McLean (2006); Ahn \& McLean, (2006) \\
\hline 15 & Quality of Work Life & Gilley and Eggland, (1989); Pace et al. (1991). \\
\hline
\end{tabular}

Source: Compiled by the author through Literature Review 
The objectives of HRD (table 1) are to ensure holistic human development, which gives a compound result to enact and accomplish the vision, mission, and strategies of an organization, nation, and region. Most of the authors agreed that micro HRD is for individual and organizational development. Hence, the outcome of HRD also increases the productivity and profitability of an organization and fosters national economic growth. Besides, HRD programs also bring about social, cultural, and political stability and enrich international relations among the countries and national alliances. However, the core objectives of HRD could be the following.

4.2.1 Physical and Mental Development: Genetic and psychological development of humans improves health condition, ensures a hygienic environment, foster educational development through schooling or institutional education, and good sociopolitical life. The absence of this objective will impede physical and mental growth, leading to low productivity and will create social destructions like some African countries. This HRD objective will be achieved through human development interventions set by a country or world communities like World Health Organization, The United Nations Children's Fund, World Food Program, etc.

4.2.2 Skill Development: Knowledge, skill, and attitudinal development of humans can be achieved by facilitating professional education, technical training, career development, employment \& entrepreneurship development program, etc. It increases national productivity, sound socio-economic development, and political stability. This objective can also be achieved through professional and career development interventions set by national policymakers, employers, professional bodies, and academic institutions.

4.2.3 Moral and Ethical Development: Individual character development program ensures devotion for national development, patriotism, and moral behavior. It is an essential part of HRD that creates the difference between developed and underdeveloped nations. Lack of moral learning leads to social, political, and economic breakdown, and event the nation, which is abundant with natural and human resources, have to face the same consequences. A morally developed nation is a developed and great nation in the modern age, and honesty, decency, integrity, patriotism, etc. are the intangible asset for the development at all stages of a country. The ethical mindset can bring economic, social, and political stability, leading to global peace, happiness, and prosperity. The developmental gap among the nations is the gap of moral behavior among the citizens of those nations. This objective can be achieved through good governance and citizenship development interventions set by national policymakers, employers, professional bodies, and academic institutions.

\subsection{Operational hierarchy of HRD}

From the operational point of view, HRD could be staged into four levels (Figure 1). Each level of HRD has its area of specialization, interventions, and output. Micro and Mezzo HRD limit their operations up to the organizational level. Hence, Macro and Mega HRD are broader in covering national and international development interests and indirectly aid the interventions of the organizational level. However, some HRD objectives and interventions are common at different levels, and these are complementary to each other at some point. Different level of HRD is discussed below.

4.3.1. Micro or functional unit level: A raw human resource joins an organization with a theoretical knowledge set. Therefore, it is the responsibility of the concerned functional department to provide the new hires primary knowledge to make him/her perform day-to-day operations aligned with the job description. Line managers or supervisors should provide individual attention to every novice to socialize them with the organizational task and culture. These HRD programs are conducted for the individual employee by the concerned department. The inputs of this level HRD could be coaching, mentoring, on-the-job training and orientation program, etc. The micro HRD ensures long-term growth and development of the organization and helps build the national economy. 
Figure 1: Levels of HRD

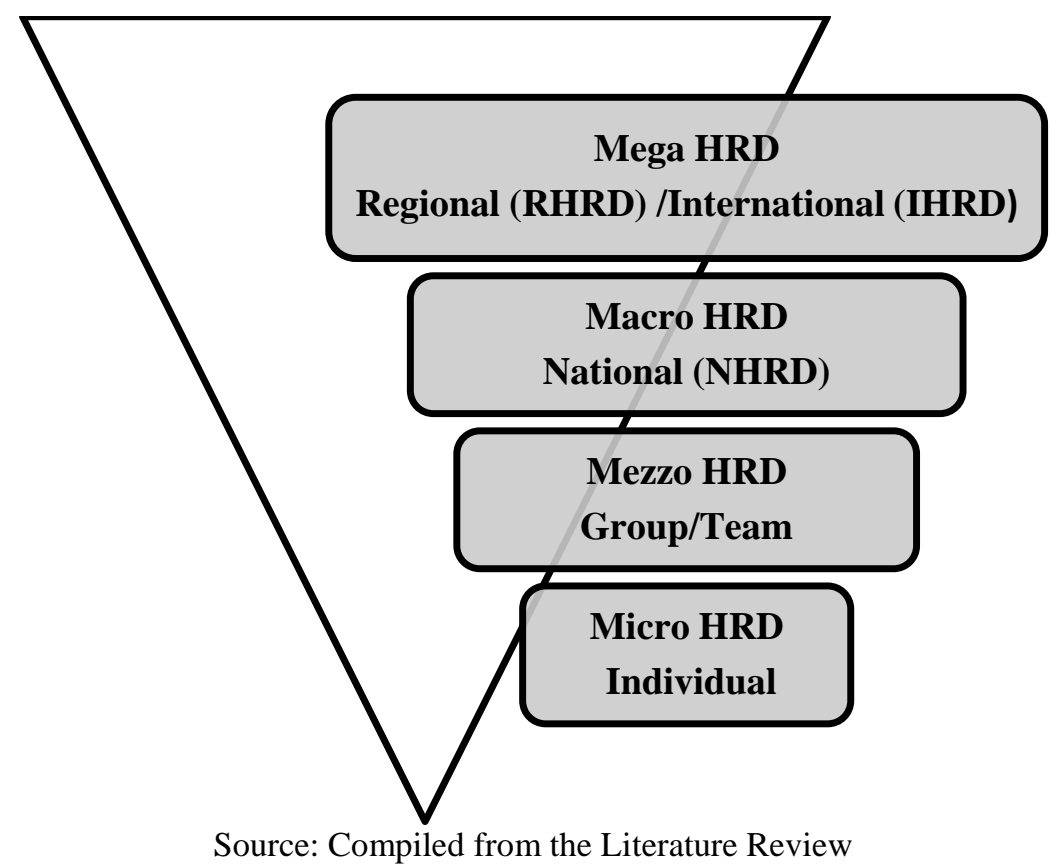

4.3.2 The mezzo-level/ HR departmental level: Mezzo level of HRD facilitates the development of human potentials at groups or teams or unit level through job restructuring activities, organizational design, research, empowerment, the collaboration, which provides collective learning experiences to the team members different functional wings of an organization. It is an extended function of HRD that is mostly conducted by the human resource (HR) department of an organization in association with the line department. At this level, the strategic requirement of $\mathrm{HRD}$ is being met through centralized training and development interventions. Some organizations create their capacity to train people, and some send their employees to different training institutes to update them with a new set of knowledge and skill. Organizations also provide training to their employees on an outsourcing basis through Job portals, professional networking sites, and professional associations. Most of the time, the human resource department conducts the following activities, i.e., human resource planning, job analysis, and talent acquisition management, training \& development interventions, performance management, compensation management, organizational development interventions, work-life balance program, career \& succession planning, counseling, developing teamwork, strategic management, etc. in the name of HRD.

4.3.3 Macro or National level: It is the responsibility of a government to develop the efficiency of employees at different levels, improving the physical, mental, and moral capacity of the working citizen for the local and international job market. Moreover, the government should take the responsibility to train the citizens to respond to various national crises, help them achieve entrepreneurial qualities, and finally infuse dedication and patriotism. Macro HRD programs intervene to develop the public health condition, provide educational opportunities, and develop infrastructural facilities to enhance citizens' productivity. It engages the citizen in income-generating activities, enriches vocational or professional capabilities, and develops positive attitudes that are obvious for a nation's holistic development and wealth generation. Central Government of the UK, South Africa, China, and Poland are taking many strategic initiatives of HRD at all levels.

The challenges of this level of HRD are to develop infrastructural facilities to impart primary education and vocational training at the grassroots level. Government agencies are assigned to develop educational content and curriculums according to national strategic requirements and promote indigenous knowledge. Governmental ministries, i.e., education ministry, employment ministry, Information \& Communication Technology ministry, Ministry of industries, youth development ministry, etc., initiate necessary programs to create human resources for local vacancies and overseas employment. The government should also provide necessary accommodation facilities, design welfare schemes, and increase employment opportunities to succeed in the HRD activities at the 
national level. The core area of macro HRD is to develop a national consensus of learning and to ensure the proper utilization of human resources. Therefore, the concepts of national HRD are mainly functions at macro strata to develop competencies in the human resources of a country through knowledge, skill, and attitude development to create a competitive and potential workforce to meet global challenges.

4.3.4 Mega or Regional Level: HRD at the mega level is understood and practiced as a human development initiative through the international or regional level coalition. It is conceptualized that there should be a spirit of shared learning among scholars, professionals, practitioners, corporate, and governments. This spirit of collaboration among the nations may help share and utilize each other's intellectual strength to enrich their citizen's lives. This initiative may facilitate the goal of continuous development and may enhance innovation across the nations. No country is entirely self-reliant and should exchange its intellectual capital through joint international programs like seminars, conferences, youth exchange programs, educational alliances, etc. Such initiatives will ensure peaceful and solvent life as in the global community. However, these HRD initiatives may minimize competition among the nations and may uphold the novel thought of global citizenship. Multinational firms may also practice RHRD for developing a culturally adaptive human resource (HR) to meet global challenges.

\subsection{Beneficiaries or Stakeholders of HRD}

From the study, it is found that there are four broad stakeholders (figure 2 and table 2) of HRD. Individuals or peoples are the most common and direct beneficiaries of HRD. HRD initiatives at the micro and mezzo level benefit the employees in many ways, like productivity improvement, a better quality of work-life, etc. Hence, the organizations also reap the benefit of profitability and growth out of that. Through the governmental interventions, common people of the country are benefited at large. Through regional cooperation among the countries, the entire world could be benefited from the outcome of HRD. The benefits of HRD are holistic and complementary to each other. Hence, an employee's productivity creates a chain effect of growth, which commonly benefits all the stakeholders of HRD. HRD is an intervention that serves the holistic purpose of an individual to the regional strategic, social, and cultural needs.

Figure 2: Beneficiaries of HRD with its implementational scopes

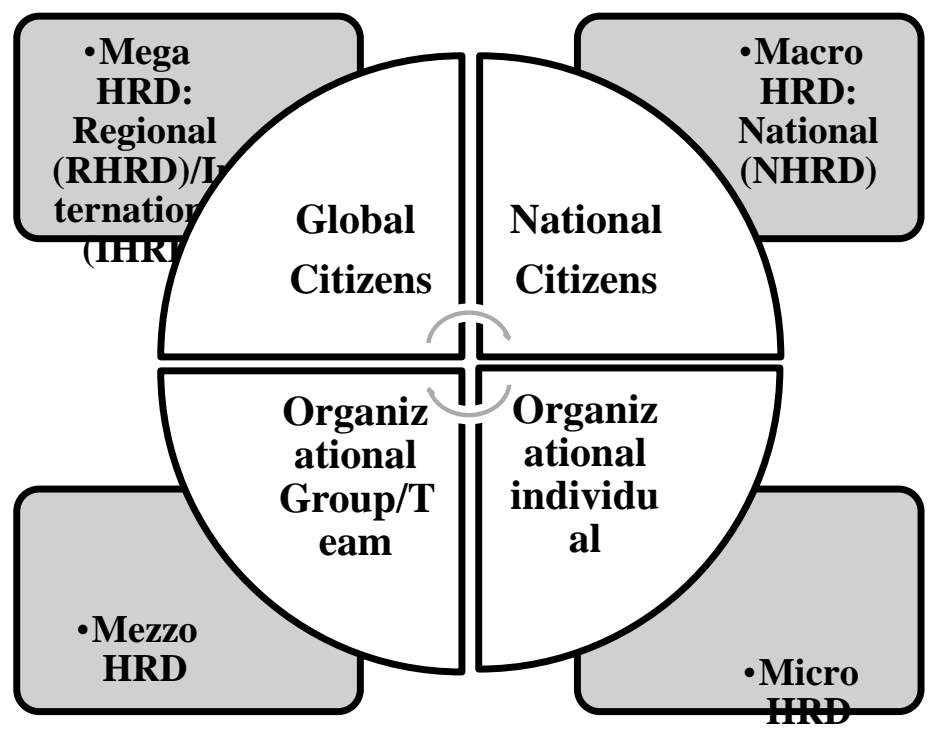

Source: Illustrated by the author 
Table 2: Beneficiaries of HRD

\begin{tabular}{|c|c|c|}
\hline SI.No & $\begin{array}{l}\text { HRD } \\
\text { Beneficiaries }\end{array}$ & Source \\
\hline 1 & $\begin{array}{l}\text { Personal/ } \\
\text { Individual }\end{array}$ & $\begin{array}{l}\text { Jones (1981); Chalofsky\& Lincoln (1983); Smith (1988);Nadler \& Nadler } \\
\text { (1989); Gilley and Egglund, (1989);Smith (1990);Garavan (1991);McLean \& McLean } \\
\text { (2001); Harrison and Kessels (2004); McLagan \&Suhadolnik (1989);Watkins } \\
\text { (1989);Stewart (1999);Hamlin (2004);Kuchinke (2003) }\end{array}$ \\
\hline 2 & $\begin{array}{l}\text { People \& } \\
\text { Group }\end{array}$ & $\begin{array}{l}\text { Harbison \& Myers, (1964);Watkins (1989);McLean \& McLean (2001);Rothwell\&Kasanas } \\
\text { (1994) }\end{array}$ \\
\hline 3 & Organization & $\begin{array}{l}\text { Jones (1981); Nadler \&Wiggs (1986);Smith (1988); Gilley \&Egglund, (1989);Smith } \\
\text { (1990); Garavan (1991);McLean \& McLean (2001); Harrison and Kessels (2004);Yorks } \\
\text { (2005); Werner \& DeSimone (2006);Swanson (1987);McLagan \&Suhadolnik } \\
\text { (1989);Watkins (1989);Watkins (1989);Stewart (1999);Hamlin (2004); Ali, (2005); } \\
\text { Kuchinke (2003) }\end{array}$ \\
\hline 4 & Society & $\begin{array}{l}\text { Harbison \& Myers, (1964);McLean \& McLean (2001); Abdullah (2009); Tome’ E. (2011); } \\
\text { Byrd, \&Demps, (2006);Sarbabidya\& Huda (2004); }\end{array}$ \\
\hline 5 & Nation & $\begin{array}{l}\text { McLean \& McLean (2001);Cho \& McLean, (2004); McLean, et al. (2012); Kim, (2012), } \\
\text { Devadas, et al. (2011); Abdullah (2009); Ali, (2005); Wang \&Swanson (2008); Byrd, } \\
\text { \&Demps, (206); Liu \& Wall (2005); Saeed \&Batool (2004); Ather\&Solaiman (1995); } \\
\text { Alagaraja (2012); Kuchinke (2003); Bécherel (2001) }\end{array}$ \\
\hline 6 & International & McLean, et al. (2012); Kim, (2012) \\
\hline 7 & Regional & Ahn, \& Mclean, (2006) \\
\hline
\end{tabular}

Source: Compiled by the author through Literature Review

\subsection{Inputs of HRD}

Most of the HRD literature had commonly discussed knowledge, skill, education, and behavioral development as the key ingredients of human resource development that should benefit an organization and people working in it, society, and the nation. Inputs of HRD are vital to ensure a favorable output of HRD and attain the objectives of HRD at large. The inputs of HRD are compiled in table 3.

Table 3: Inputs of HRD

\begin{tabular}{|l|l|l|}
\hline SI No & \multicolumn{1}{|c|}{ Inputs } & \multicolumn{1}{c|}{ Source } \\
\hline $\mathbf{1}$ & Knowledge & Harbison \& Myers, (1964); Gilley and Egglund, (1989);McLean \& \\
\hline $\mathbf{2}$ & Skills & $\begin{array}{l}\text { McLean (2001);Harrison \& Kessels (2004); Rothwell \& Kasanas (1994);Tome’ } \\
(2011) ; \text { Abdullah (2009); Kuchinke (2003) }\end{array}$ \\
\hline $\mathbf{3}$ & Education & $\begin{array}{l}\text { Harbison \& Myers (1964), Gilley \& Egglund, (1989);Werner \& DeSimone (2006), } \\
\text { Swanson \& Sleezer (1987); Rothwell \& Kasanas (1994); Abdullah (2009); Ali } \\
\text { (2005); Kuchinke (2003) }\end{array}$ \\
\hline $\mathbf{4}$ & Workability & Smith (1990); Garavan (1991); McLagan (1989). \\
\hline
\end{tabular}


MAPPING THE DIMENSIONS OF HUMAN RESOURCES DEVELOPMENT: A SCOPING REVIEW

KAZI NAZMUL HUDA

\begin{tabular}{|l|l|l|}
\hline $\mathbf{5}$ & Learning & Jones (1981);Werner \& DeSimone (2006); Yorks (2005); Watkins (1989) \\
\hline $\mathbf{6}$ & Behavior & $\begin{array}{l}\text { Chalofsky \& Lincoln (1983);Nadler \& Wiggs (1986); Nadler \& Nadler (1989); } \\
\text { Ruona \& Lynham (1999);Harrison \& Kessels (2004);Stewart (1999); Watkins (2000); } \\
\text { Hamlin (2004) }\end{array}$ \\
\hline $\mathbf{7}$ & Leadership & Nadler (1970); Gilley \& Egglund (1989); Meggisson et al. (1993) \\
\hline $\mathbf{8}$ & Ethics & Smith (1990) \\
\hline
\end{tabular}

Source: Compiled by the author through Literature Review

\subsection{Interventions of HRD}

Interventions are actions or programs that facilitate the process of HRD (Table 4) to achieve the objectives of HRD. Most of the authors discussed training, formal education, organizational development initiatives, and career development programs as HRD interventions. Training is a common intervention provided by the organizations to develop the performance of employees and management peoples. Most of the HRD interventions should be aided by the government, including infrastructural facilities for formal education, public health, and employment. If the government could ensure essential facilities for NHRD, it will be easier for the organizations to initiate additional conveniences to ensure the productivity and performance of human resources. The interventions of HRD are compiled in table 4.

Table 4: Interventions of HRD

\begin{tabular}{|c|c|c|}
\hline & Interventions & Source \\
\hline 1 & Training & $\begin{array}{l}\text { Smith (1990); Garavan (1991); McLagan \& Suhadolnik (1989); Watkins } \\
\text { (1989); Swanson (1995);Kashem \& Guha (2000); Ali, (2005); Liu \& Wall } \\
\text { (2005); Kashem \& Guha (2000); Kashem \& Guha (2000); Tariq Khan } \\
\text { (2013), }\end{array}$ \\
\hline & Coaching & Grant (2001); Hamlin et al. (2009) \\
\hline 2 & Institutional Education & $\begin{array}{l}\text { McLean (2006); Ali, (2005); Liu \& Wall (2005); Kashem\&Guha (2000); } \\
\text { Ather \& Solaiman (1995); Alagaraja (2012); }\end{array}$ \\
\hline 3 & Work design & Swanson (1987) \\
\hline 4 & $\begin{array}{l}\text { Organizational } \\
\text { Development \& Change }\end{array}$ & $\begin{array}{l}\text { McLagan \& Suhadolnik (1989), Watkins (1989);Rothwell \& Kasanas } \\
\text { (1994);Swanson (1995);Watkins (2000);Ahn \& McLean, (2006) }\end{array}$ \\
\hline 5 & Career Development & McLagan \& Suhadolnik (1989); Watkins (1989);Ahn\& McLean, (2006) \\
\hline 6 & Access to resources & Yorks (2005); McLean (2006) \\
\hline 8 & Health Initiatives & McLean (2006) \\
\hline 9 & $\begin{array}{l}\text { Technological } \\
\text { Development }\end{array}$ & McLean (2006); Ali (2005) \\
\hline 10 & $\begin{array}{l}\text { Infrastructure } \\
\text { Development }\end{array}$ & McLean (2006) \\
\hline 11 & Safety Initiatives & McLean (2006) \\
\hline 12 & On-the-job learning & Nadler \& Wiggs (1986); McLean \& McLean (2001) \\
\hline 13 & $\begin{array}{l}\text { Management } \\
\text { development Program }\end{array}$ & Swanson (1987) \\
\hline
\end{tabular}

Source: Compiled by the author through Literature Review 


\subsection{Outputs of HRD}

The outputs of HRD are to enhance competency, employee motivation \& job satisfaction, loyalty \& commitment, cooperation, teamwork, etc. which helps an organization to reach the ultimate. The output of HRD finally facilitates in attain the outcome of the organization. The essential variables of HRD outputs are listed in Table 5.

Table 5: Output of HRD

\begin{tabular}{|c|c|c|}
\hline & Outputs & Source \\
\hline 1 & Competency & Harbison \& Myers (1964); Swanson \& Sleezer (1987) \\
\hline 2 & Physical development & Kashem \& Guha (2000) \\
\hline 3 & Mental/ psychological & Kashem \& Guha (2000) \\
\hline 4 & Motivation & Khan et al. (2012); Rigby \& Ryan (2018) \\
\hline 5 & Job satisfaction & Gilley and Egglund (1989); Solkhe \& Chaudhary (2011) \\
\hline 6 & Loyalty & Venkateswaran (1997) \\
\hline 7 & Commitment & Kuchinke (2003) \\
\hline 8 & Collaboration & Harrison \& Kessels (2004) \\
\hline 9 & Cooperation & McLean \& McLean (2001) Pattanayak (2003) \\
\hline 10 & Teamwork & Stone (2010) \\
\hline 11 & Adaptability & Harrison \& Kessels (2004); Rothwell \& Kasanas (1994) \\
\hline 12 & Self-renewal & Potnuru \& Sahoo (2016). \\
\hline 13 & Professional development & Gilley \& Egglund (1989); Yorks (2005) \\
\hline 14 & Empowerment & Metcalfe (2011) \\
\hline
\end{tabular}

Source: Compiled by the author through Literature Review

\subsection{Outcomes of HRD}

The outcomes of HRD are to ensure productivity, profitability, competitive advantage, and sustainability of an organization, society, country, and mostly the world community. It will make the world free from poverty and minimize tension and conflict among men and nations. The essential factors of HRD outcomes are listed in Table 6.

Table 6: Outcomes of HRD

\begin{tabular}{|l|l|l|}
\hline & Outputs & Source \\
\hline 1 & Productivity & Swanson (2001); McLean (2006) \\
\hline 2 & Profitability & Garavan (1991); Swanson (1995) \\
\hline 3 & Competitive Advantage & Osman-Gani, (2004); Lynham and Cunningham, (2004) \\
\hline 4 & Social Balance & Yang, Zhan, and Zhang, (2004); Lutta-Mukhebi, (2004); Lee, (2004) \\
\hline 5 & Sustainability & Ardichvili (2011); Scully-Russ (2012) \\
\hline
\end{tabular}

Source: Compiled by the author through Literature Review 


\section{CONCLUSION AND FUTURE RESEARCH POTENTIAL}

This study has discovered the critical dimensions of HRD and categorized them in objectives of HRD, its operational levels, key stakeholders/beneficiaries, inputs, outputs, outcomes of an HRD system, and its interventions. HRD interventions focus on developing human capability through public and private investment, productive use of those human recourses in different economic capacities, and encouraging/motivating the human resources to develop a better society to live. The outcome of HRD is, directly and indirectly, contributing all the levels of Micro, Mezzo, and Mega HRD. The functions of modern HRD go beyond the organizational venture of traditional employee training and development programs and ensure the physical, mental, and moral development of an employee at the micro-level. However, at the macro-level of HRD, citizens are developed with physical and mental endurance, soft \& hard skill, and, most significantly, moral \& ethical development that keeps a nation free from corruption and evil deeds.

Human resources are indeed acknowledged as the most efficient input in achieving objective results for an organization. However, to develop the necessary skills, knowledge, organizational behavior, and proficiency of this precious asset, it is extremely imperative for the sustainable growth and development of an enterprise of the $21^{\text {st }}$ century. Traditionally, HRD is practiced in the form of training and development activities in many organizations. Hence, in modern days the dimension of HRD is increasing day by day as a strategic activity for an organization. To promote the employees with multiple skills and knowledge and prepare them to face the everchanging business environment, the result-oriented practice of HRD is obligatory. It is also an adaptation process for the workforce to face the challenges of a competitive environment as the HRD programs make them changefriendly. Every HRD initiative should be facilitated by well-designed interventions to achieve its stakeholder's objectives and goals of the society at large.

The author of the study has endeavored to discuss the concurrent and contextual dimensions of HRD by clustering secondary literature into a categorized knowledge of HRD to develop a comprehensive literature base to aid future researches on HRD. Researchers may prefer to investigate the empirical validity of the proposed variables of HRD extensively, and the HRD practitioners may use the items revealed from the study to diagnose the HRD health of an organization through a survey. We have to journey a great distance to conceptualize the context, concepts, principles, and practices of HRD, and such a comprehensive paper may facilitate future researchers to develop further knowledge.

\section{REFERENCE}

ABDULLAH, H. Definitions of HRD: Key Concepts from a national and international context. European Journal of Social Sciences, 10 (4), 486-495, 2009.

AHN, Y. S., \& MCLEAN, G. N. Regional human resource development: The case of Busan City, Korea. Human Resource Development International, 9(2), 261-270, 2006.

ALAGARAJA, M. National Human Resource Development in practice: an interview with M.V. Subbiah, Human Resource Development International,15(4), 2012.

ALAGARAJA, M., \& GITHENS, R. P. Capacity and capability building for national HRD: A multi-level conceptual framework. Human Resource Development Review, 15(1), 77-100, 2016.

ALI, K. S. Challenges in Human resource Development: Asian Perspective, Phoshikhyan, A journal of Training and Development,13 (2), 2005.

ALI, M. E. Human Resource Development in the perspective of Secondary Education In Bangladesh, Bangladesh Islami University journal,2(1), 2008. 
ARDICHVILI, A. Sustainability of nations, communities, organizations and individuals: the role of HRD. Human Resource Development International, 14(4), 371-374, 2011.

ARYA, P. and TANDON, B. Human Resource Development, $3^{\text {rd }}$ edition, Deep and Deep Publications, F159, Rajouri Garden, New Delhi, 03, 1998.

ATHER, S. M. \& SOLAIMAN, M. Human resource Development practices in Bangladesh - a study on some selected firms in Chittagong, Chittagong University Studies Commerce, 11, 19-37, 1995.

BAEK, S. J. Jiyeokinjeokjawongaebal-gwajiyeokhyeksin system, (Regional human resource development and regional innovation system). Vision and strategy for HRD of Busan: Symposium report, 47-92, 2002.

BATES, R., CHIH CHEN, H., \& HATCHER, T. Value priorities of HRD scholars and practitioners. International Journal of Training and development, 6(4), 229-339, 2002.

BÉCHEREL, L. A framework for human resources development strategy at the macro-level: A situational analysis of tourism human resources in Bahia, Brazil. International journal of hospitality \& tourism administration, 1(3-4), 73-97, 2001.

BIKAS, C., SANYAL. Education, employment and human resource development Chapter 2, Education, employment and human resource development in selected East Asian and Pacific countries: an overview, International Institute for educational planning, Korean Educational Development Institute, UNESCO Principal Regional Office for Asia and the Pacific, 1992.

BRIGGS, V. M. Human resource development and the formulation of national economic policy. Journal of Economic Issues, 21(3), 1207-1240, 1987.

BROAD, M. L. and NEWSTROM, J. W. Transfer of Training: Action Packed Strategies to Ensure High Payoff from Training Investments (Reading, MA: Addison-Wesley), 1992.

BYRD, M. \& DEMPS, E. Taking a look at National Human Resource Development (NHRD): Interviews with Gary Mclean and Susan Lynham, Human Resource Development International,9(4), 553 - 561, 2006.

COLLINS, J. C., ZARESTKY, J., \& TKACHENKO, O. (2017). An integrated model of national HRD and critical HRD: Considering new possibilities for human resource development. Human Resource Development International, 20(3), 236-252, 2017.

COLQUHOUN, H. L., LEVAC, D., O'BRIEN, K. K., STRAUS, S., TRICCO, A. C., PERRIER, L., \& MOHER, D. Scoping reviews: time for clarity in definition, methods, and reporting. Journal of clinical epidemiology, 67(12), 1291-1294, 2014.

CHALOFSKY, N. and LINCOLN, C. Up the HRD Ladder, Addison-Wesley, Reading, MA, 1983.

CHICAGO SARFIN, R.L. The History of Human Resource Development, bizfluent.com. Retrieved from: https://bizfluent.com/info-7737165-history-human-resource-development.html 2017, September 26.

CHO, E. \& MCLEAN, G. N. "What we discovered about NHRD and what it means for HRD", Advances in Developing Human Resources, 6(3) 382-93, 2004.

CUNLIFFE, A. L., \& EASTERBY-SMITH, M. From reflection to practical reflexivity: Experiential learning as lived experience. In Organizing reflection, 44-60, 2017. 
DEVADAS, U. M., SILONG, A. D., \& KRAUSS, S. E. Human resource development and the contemporary challenges of the world. Journal of Management Policy and Practice,12(5), 128-141, 2011.

FENWICK, T. Conceptions of Critical HRD: Dilemmas for Theory and Practice. Human Resource Development International, 8(2), 225-238, 2005.

FORD, D. J. Benchmarking HRD. Training \& Development, 47(6), 36-42, 1993.

GARAVAN, T. "Strategic human resource development", Journal of European Industrial Training,15, 17-30, 1991.

GEORGE, M. A. Chairperson, Department of Health Administration and Human Resource, College of Health, Education and Human Resources, University of Scranton, Scranton, Pa, USA 18510, 2000.

GILLEY, J.W. and EGGLUND, S.A. Principles of Human Resource Development,Addison-Wesley, Reading, MA, 1989.

GUNNARSSON, R. Writing a systematic review, Science Network TV. Retrieved from https://sciencenetwork.tv/writing-a-systematic-review/, 2020, June 22.

GRANT, A.M. Towards a Psychology of Coaching, Coaching Psychology Unit, School of Psychology, University of Sydney, Sydney, Retrieved from: www.psych.su.oz.au/psychcoach/Coaching_review_AMG2001.pdf, 2001.

GREENBERG, J. \& BARON, R. A. Behavior in organizations: Understanding and managing the Human side of work, Prentice-Hall, 1997.

HAMLIN, R.G., ELLINGER, A.D. and Beattie, R.S. "Toward a profession of coaching? A definitional examination of 'coaching,' 'organization development,' and 'human resource development'”, International Journal of Evidence-based Coaching and Mentoring,7(1)13-38, 2009.

HAMLIN, B., \& STEWART, J. What is HRD? A definitional review and synthesis of the HRD domain. Journal of European Industrial Training, 35(3), 199-220, 2011.

HAMLIN, R.G. "Toward evidence-based HRD through HRD professional partnership research", Inaugural Professorial Lecture, University of Wolverhampton, Wolverhampton, 2004.

HARBISON, F. H. and MYERS, C. A. Education, Manpower and Economic Growth: Strategies of Human Resource Development, McGraw-Hill, NY, 1964.

HARRISON, R. and KESSELS, J. Human Resource Development in a Knowledge Economy: An Organizational View, Palgrave Macmillan, Basingstoke, 2004.

HATCHER, T. Ethics and HRD: A new approach to leading responsible organizations. Perseus Publishing, 2010.

HUDA, K. N., KARIM, R.,\& AHMED, F. Practices of strategic human resource development

in the RMG sector of Bangladesh: An Empirical Study. International Business Management, 1(1), 7-11, 2007.

HUDA, K. N., ANIKA, T.,R., \& KHALED, M., C. Strategic Human Resource Development Practices: An Empirical Study of Steel Manufacturing Industries of Bangladesh, International Management Review, 10 (2), 24$31,2014$. 
HUDA, K. N. Stakeholders' Engagement in Youth's Organizations for National Human

Resource Development: A Study on Bangladesh National Cadet Corps. Journal of Management, 7(4), 11-22, 2020 .

JAYAGOPAL, R. Human Resource Development Conceptual analysis and strategies, $1^{\text {st }}$ edition, Sterling Publishers Pvt. Ltd, New Delhi- 1100291, 02, 1990.

JONES, J. The 1981 Annual Handbook for Group Facilitators, University Associates, San Diego, CA, 1981.

KANG, M. S. Directions and projects of regional human resource development related with national human resource development, in: D. K. Seol (Ed.) Vision and Strategies forRegional Human Resource Development in Busan: Symposium Report, 3 - 10, 2002.

KASHEM, M. M. \& GUHA, R. K. Human resource development through training: the case of CVDP, Phoshikhyan, A journal of Training and Development,8(2), 2000.

KHAN, T., KHAN N. A.\& Mahmood K,. An Organizational Concept of Human Resource Development - How Human Resource Management Scholars View 'HRD' (Literature Review) Universal Journal of Management and Social Sciences, 2 (5), 2012.

KIM, N. Societal Development through Human Resource Development Contexts and Key Change Agents, Advances in Developing Human Resources, 14, 2012.

KUCHINKE, K. P. Comparing national systems of human resource development: role and function of postbaccalaureate HRD courses of study in the UK and US. Human Resource Development International, 6(3), 285299, 2003.

LASHLEY, C. \& WATSON, S. Researching Human Resources Management in the Hospitality Industry: The Need for a New Agenda? International Journal of Tourism and Hospitality Research1 (1), 19-40, 1999.

LIU, A. \& WALL G. Human Resources Development In China, Annals of Tourism Research,32(3), 689-710, 2005.

LUTTA-MUKHEBI, M. C. National Human Resource Development policy in Kenya. Advances in Developing Human Resources, 6(3), 326-333, 2004.

LYNHAM, S. A., \& CUNNINGHAM, P. W. Human Resource Development: The South African Case. Advances in Developing Human Resources,6(3), 315-325, 2004.

MCLEAN, G. N., \& JIANTREERANGKOO, B. The role of national HRD in an era of COVID-19. Human Resource Development International, 23(4), 418-426, 2020.

MCLAGAN, P. and SUHADOLNIK, D. Models for HRD Practice: The Research Report, American Society for Training and Development, Alexandria, VA, 1989.

MCLEAN, G., N, KUO, M., BUDHWANI, N., N., YAMNILL, S., and VIRAKUL, B. Capacity Building for Societal Development Case Studies in Human Resource Development, Advances in Developing Human Resources, 14(3), 251-263, 2012.

MCLEAN, G. N. National Human Resource Development: what in the world is it? Advances in Developing Human Resources,6(3) 269-275, 2004. 
MCLEAN, G.N. and MCLEAN, L. "If we can't define HRD in one country, how can we define it in an international context?", Human Resource Development International, 4 (3), 313-26, 2001.

MCGOLDRICK, J., STEWART, J. and WATSON, S. "Theorizing human resource development", Human Resource Development International,4 (3),343-56, 2001.

MEGGISSON, D., JOY-MATTHEWS, J. and BANFIELD, P. Human Resource Development, Kogan Page, London, 1993.

METCALFE, B. D., \& REES, C. J. Theorizing advances in international human resource development. Human Resource Development International, 8(4), 449-465, 2005.

METCALFE, B. D. Women, empowerment and development in Arab Gulf States: a critical appraisal of governance, culture and national human resource development (HRD) frameworks, Human Resource Development International,14(2), 131-148, 2011.

MEZEI, Z., \& FODOR, P. Human Resources Development in a Lagging Region. Far East Journal of Psychology and Business, 7(5), 56-68, 2012.

NADLER, L. Developing Human Resources, Gulf, Houston, TX, 1970.

NADLER, L. and NADLER, Z. Developing Human Resources: Concepts and a Model, 3rd ed.,Jossey-Bass, San Francisco, CA, 1989.

NADLER, L. and WIGGS, C. Managing Human Resource Development: A Practical Guide, Berrett-Koehler, San Francisco, CA, 1986.

OSMAN-GANI, A. Human Capital Development in Singapore: An Analysis of National Policy Perspectives. Advances in Developing Human Resources, 6(3), 276-287, 2004.

PACE, R. W., SMITH, P. C. and Mills, G. E. Human Resource Development: The Field (Englewood Cliffs, NJ: Prentice-Hall), 1991.

PANDE, R.S., TROPP, S., SHARMA, B., and KHATIWADA, Y. R, Nepal: Readings in Human Development, United Nations Development Programme, 2006.

PATTANAYAK, B. “Human Resource Management”,Prentice Hall of India Private Ltd, 2003.

PETERS, M. D., GODFREY, C. M., KHALIL, H., MCINERNEY, P., PARKER, D., \& SOARES, C. B. Guidance for conducting systematic scoping reviews. International journal of evidence-based healthcare, 13(3), 141-146, 2015.

POTNURU, R. K. G., \& SAHOO, C. K. HRD interventions, employee competencies and organizational effectiveness: an empirical study. European Journal of Training and Development. 40(5), 345-365, 2016.

RAO, T. V. Human Resource Development Experiences Interventions, Strategies, $6^{\text {th }}$ printing, SAGE Publications Inc, 6 Bonhill Street London EC2A 4PU, 2000.

RAWAT, S. Human Resource Development at Micro and Macro Level, Retrieved shvoong.com: www.shvoong.com/business-management/1813041-human-resource-development

micramacro/\#ixzz2MqXT9xZIShvoong, 2008. 
RIGBY, C. S., \& RYAN, R. M. Self-determination theory in human resource development: New directions and practical considerations. Advances in Developing Human Resources, 20(2), 133-147, 2018.

ROTHWELL, W.J. and KASANAS, H.C. Human Resource Development: A Strategic Approach, HRD Press, Amerst, MA, 1994.

RUONA, W.E.A. and LYNHAM, S. "Toward a philosophical framework of thought and practice", in Kuchinke, K.P. (Ed.), AHRD Conference Proceedings, 206-15, 1999.

SAEED, A. \& BATOOL, S. Education and the HR Challenges, Human Resource Development Network, JANMAR. Retrieved from: www.hrdn.net/home/downloadpub/57, 2004.

SARBABIDYA, S. \& HUDA, K. N. "How Human Resource Development and Social Development Issues are Inter-related: An Empirical Study on Bangladesh”The Journal of Business and Society, 2(1), 2004.

SARFIN, R.L. The History of Human Resource Development, bizfluent.com. Retrieved from: https://bizfluent.com/info-7737165-history-human-resource-development.html 2017, September 26.

SEN, A. Human Resource: Development Planning \& deployment, Asian Books Private Ltd, New Delhi, 2007.

SENAPATY, S. Towards Sustainable CSR: Analyzing Macro level HRD Issues. Philosophy of Management, 9(3), 65-75, 2010.

SOLKHE, A., \& CHAUDHARY, N. HRD climate and job satisfaction: An empirical

investigation. International Journal of Computing and Business Research, 2(2), 1-20, 2011.

SCULLY-RUSS, E. Human resource development and sustainability: beyond sustainable organizations. Human Resource Development International,15 (4), 399-415, 2012.

SMITH, D. The Dictionary for Human Resource Development, ASTD Press, Alexandria, VA, 1990.

STEWART, J.D. Employee Development Practice, FT Pitman Publishing, London, 1999.

STONE, K. B. Kaizen teams: Integrated HRD practices for successful team building. Advances in developing human resources, 12(1), 61-77, 2010.

SWANSON, R.A. Human Resource Development Definition: University of Minnesota, Training and Development Research Center, St Paul, MN, 1987.

SWANSON, R.A. "Performance is key", Human Resource Development Quarterly, 6 (2), 207-13, 1995.

SWANSON, R. A., HOLTON, E., \& HOLTON, E. F. Foundations of human resource development. BerrettKoehler Publishers, 2001.

TOMÉ, E. Human resource development in the knowledge based and services driven economy: an introduction. Journal of European Industrial Training, 35(6), 524-539, 2011.

TREGASKIS, O., HERATY, N., \& MORLEY, M. (2001). HRD in multinationals: the global/localmix. Human resource management journal, 11(2), 34-56. 
VENKATESWARAN, K. P. S. (1997). A note on HRD climate. Vikalpa, 22(1), 51-54.

WALTON, J. The provision of learning support for non-employees. Human Resource Development: Perspectives, Strategies, and Practice, 120-37, 1996.

WANG, X., \& MCLEAN, G. N. The dilemma of defining international human resource development. Human Resource Development Review, 6(1), 96-108, 2007.

WANG, G. G. \& SWANSON, R. A. The idea of national human resource development: An analysis based on economics and theory development methodology. Human Resource Development Review,7 (1). 79-106, 2008.

WATKINS, K. "Business and industry", in Merriam, S. and Cunningham, P. (Eds), Handbook of Adult and Continuing Education, Jossey-Bass, San Francisco, CA, 422-30, 1989.

WATKINS, K. (2000). “Aims, roles and structures for human resource development”, Advances in Developing Human Resources: Philosophical Foundations of Human Resource Development Practice, 17, 54-59.

WERNER, J.M. and DESIMONE, R.L. Human Resource Development, 4th ed., Thomson South-Western, Mason, OH, 2006.

YANG, B., Zangd., and Zang, M. National Human Resources Development in the Republic of China. Advances in Developing Human Resources, 3(6), 297-306, 2004.

YORKS, L. Strategic Human Resource Development, Thomson South-Western, Mason, OH, 2005. 